\title{
The palaeolimnological record from lake Cullulleraine, lower Murray River (south-east Australia): implications for understanding riverine histories
}

\author{
Jennie Fluin $\cdot$ John Tibby $\cdot$ Peter Gell
}

\begin{abstract}
Australia's largest river system, the Murray-Darling Basin, is the focus of scientific and political attention, due mainly to the competing issues of economic productivity versus environmental flows. Central to this dialogue is the need to know about the Basin's natural condition and the degree to which the system has deviated from this pre-disturbance, baseline status. This study examines the patterns of ecological change in Lake Cullulleraine, a permanently connected artificial wetland adjacent to Lock Nine on the Murray River, south-east Australia. A 43$\mathrm{cm}$ sediment core was collected in January 1998 and diatoms were analysed at $1-\mathrm{cm}$ intervals for use as aquatic ecological indicators. The sediment core was dated using ${ }^{210} \mathrm{~Pb}$. Changes in the diatom community have occurred since the time of lake formation in 1926, particularly shifts between Aulacoseira subborealis, Staurosira construens var. venter, Aulacoseira granulata, Staurosirella pinnata and Pseudostaurosira brevistriata. An electrical conductivity (EC)
\end{abstract}

\footnotetext{
J. Fluin $(\square)$

Earth and Environmental Science, University of Adelaide, Adelaide 5005, Australia

e-mail: jennie.fluin@adelaide.edu.au

J. Tibby

Geography and Environmental Studies, University of Adelaide, Adelaide, SA 5005, Australia

P. Gell

University of Ballarat, Ballarat, VIC, Australia
}

transfer function was applied to the fossil diatom assemblages and inferred EC values were compared to long-term, historical EC data from the River. Despite the presence of good analogues between fossil and modern diatom assemblages, inferred EC did not reflect measured EC accurately. In recent decades, patterns in the two data sets were reversed. Despite clear changes in the fossil record, quantitative palaeo-environmental interpretation was limited because the dominant taxa occupy broad ecological niches. Despite these limitations, changes in the Lake Cullulleraine record, particularly in the planktonic taxa, can be interpreted in terms of landscape change. Furthermore, because of the good chronology from the site, the record may be useful for dating changes observed in sites with poor chronological control.

Keywords Palaeoecology · Diatoms . Murray river $\cdot$ Autecology

\section{Introduction}

The Murray River, which drains the largest externally debouching drainage basin in Australia, is in a critical ecological state. Changes in flow regime, principally through regulation and irrigation, water quality, and wetland alteration, in the context of a shifting global climate, place the system under enormous pressure. 
An understanding of the long-term dynamics and variability of this system is crucial to the successful implementation of management strategies.

Many wetlands in the Murray-Darling Basin are permanently attached to the main channel, due to artificial maintenance of stable water levels, and have therefore been subjected to substantial increases in sediment, nutrient and salinity loadings since the onset of non-indigenous settlement (Mackay 1988). River regulation, an engineering process initiated in the early 1900s, caused modification of much of the Basin through weirs, locks and water storages, and greatly decreased the system's resilience to increased loadings by eliminating the natural wet/dry (or flushing) cycle. In the absence of ecologically important periodic floods, many wetlands become too saline to support a diverse fauna and are at risk of becoming "terrestrialised" due to rapid acceleration of lake ontogeny, with sedimentation rates up to $2 \mathrm{~cm} /$ year in some wetlands (Gell et al. 2006). With regular water quality monitoring within the Basin commencing in the late 1970s, $>50$ years after the commencement of river regulation, environmental proxies such as fossilised remains in the sediment, must be used to reconstruct historical environmental variability. Once variability over a longer timescale is established and placed in the context of known perturbations, either natural or anthropogenic, ecological characterisation can be undertaken.

The number of diatom-based palaeolimnological analyses in temperate Australian aquatic systems has increased in the past 5 years, with the majority of research focused on the Murray-Darling Basin (Gell et al. 2002, 2005, 2006, 2007; Tibby et al. 2003, 2007; Reid et al. 2002; Tibby and Reid 2004; Fluin et al. 2007). Results have generally shown increases in electrical conductivity (EC), $\mathrm{pH}$ and nutrients following non-indigenous settlement (Tibby et al. 2003; Gell et al. 2005, 2007; Fluin et al. 2007), changes in the composition of aquatic flora (Reid et al. 2007), increases in sedimentation rates (Gell et al. 2006), and switches from ephemeral to permanently inundated basins (Fluin et al. 2007). These studies aimed to reconstruct conditions in wetlands themselves and assess the overall health in the Murray-Darling Basin.

Many of these regional studies adopted quantitative reconstruction techniques such as weighted averaging calibration to document trends in key environmental variables through time (Tibby et al. 2003; Gell et al. 2005, 2007). Weighted averaging regression is based on the assumption that diatom taxa have an optimum along environmental gradients at which their abundance is greatest. Briefly, the method involves estimating the environmental variable $(x)$ optimum for a particular taxon by averaging all the $x$ values for sites in which the taxon occurs, weighted by the taxon's relative abundance. Although these models have robust performance (measured by internal model testing procedures such as jack-knifing) and there are adequate analogues between modern and fossil samples, there has been an absence of independent testing to assess whether the quantitative models applied in the Basin accurately represent historical trends in water quality.

This study provided an opportunity to assess the applicability of quantitative reconstructions to a system as highly variable as the Murray-Darling Basin by comparing inferred to measured EC values over a 60-year period. EC was chosen as the focus variable because there were long historical records of EC, extending back to 1938, compared to 1978 for variables such as $\mathrm{pH}$ and nutrients. Additionally, earlier work by Gell et al. (2005, 2006, 2007) showed that EC is commonly a primary driver of ecological change in Murray River wetlands.

\section{Study area}

The Murray-Darling Basin, covering 1,061,469 km², incorporates both the Murray and Darling Rivers, and in the southern part of the Basin, the substantial Murrumbidgee, Lachlan, and Goulburn Rivers. The Murray River rises in the Australian Alps about $40 \mathrm{~km}$ south of Mt. Kosciusko, and flows northwest through New South Wales, Victoria and South Australia before entering the terminal lakes system of Lake Alexandrina, Lake Albert and the Coorong at the river mouth. It is Australia's largest river basin and also one of the world's major river systems, ranking 15th in terms of length and 21 st in terms of area (Kurian 1989). Despite the large catchment size, discharge rates are very low with a mean discharge of 0.4 ML/sec compared to 7.0 ML/sec for the Danube in Europe and the Nelson in North America, respectively, rivers with comparable catchment sizes (Crabb 1993). 
Regular monitoring of salinity (as EC) in the Murray River commenced in 1938 at Morgan in South Australia. Comprehensive water quality monitoring, involving sampling from 35 sites and including nutrients and turbidity, commenced in 1978, and monitoring of macroinvertebrates and phytoplankton was initiated in 1980 (Mackay 1988). Water quality measures presently of most concern to managers and users of lower Murray River water are EC, turbidity and nutrients, with distinct spatial and temporal differences in these variables along the length of the channel. Water quality generally declines downstream, but some variables are notably dynamic (e.g. turbidity and nutrients), reflecting changing catchment land use and channel geomorphology. The lower Murray River (downstream of Mildura), where this research was done, has recent (1995-2000, Murray-Darling Basin Commission) average EC values between 250 and $1,200 \mu \mathrm{S} \mathrm{cm}^{-1}$, average total phosphorus (TP) values between 20 and $130 \mu \mathrm{g} / \mathrm{l}$, and average turbidity between 5 and 100 NTU. pH is alkaline (generally $>8$ ).
This study investigates salinity trends in Lake Cullulleraine, a wetland with permanent hydrological connection to the Murray River, located approximately $50 \mathrm{~km}$ downstream of Mildura (Fig. 1). Lake Cullulleraine was originally an ephemeral wetland that would have only received water during a major river flood. Due to its lower elevation relative to the river channel, it was identified as an ideal water storage area to support the growing cropping industry during the 1920s. In 1926, Lock 9 was constructed on the Murray River and water was pumped $9 \mathrm{~km}$ through an open channel (converted to a pipeline in 1975) to the lake. Presently the lake covers 250 ha and has a capacity of 2,460 ML. The lake is surrounded by agricultural land, predominantly vineyards, and uncultivated red sand hills. There is a small campground located on the southern and eastern shores.

Lake Cullulleraine was selected as a test site due to its minimal complexity relative to other wetlands arising from its permanent connection to the Murray River, stable water level, and consequent absence of a wet/dry regime. These factors, in combination with
Fig. 1 Map of Lake Cullulleraine showing the coring location. Inset map showing the location of Lake Cullulleraine on the lower Murray River

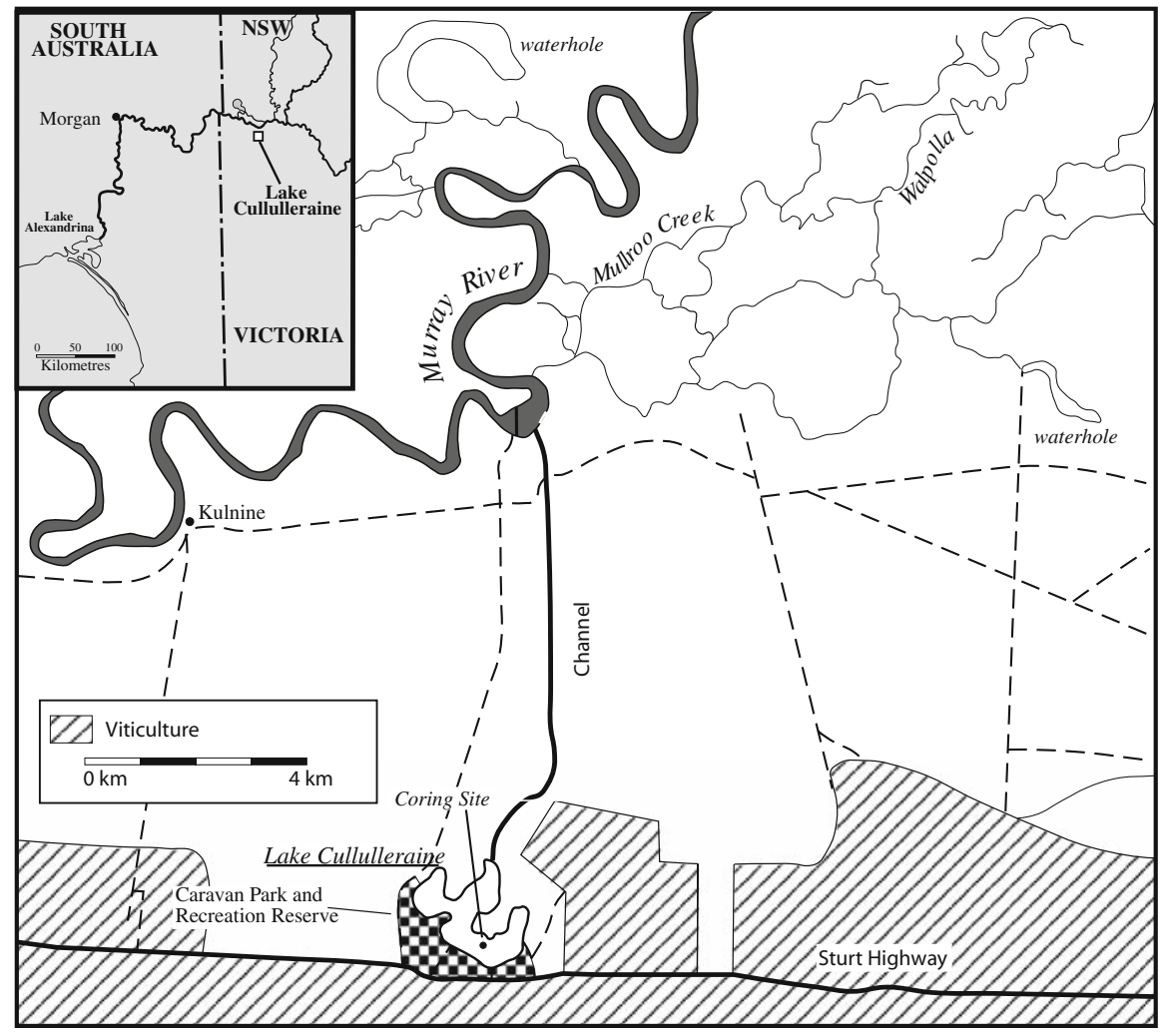


an apparently robust sediment chronology, permitted assessment of the degree to which the signal from the River Murray is modulated by individual wetland processes. Lake Cullulleraine is fed directly by the main Murray River channel which is the only surface flow into the wetland. There is negligible groundwater inflow. The lake is primarily a holding basin for irrigation. Due to high demand from surrounding agricultural land, water supply from the river is constant and lake residence time is relatively short, usually 20-60 days, depending on the season. Additionally, water levels have been maintained to within $40 \mathrm{~mm}$ since the lake's initial development, thus reducing localised EC changes due to lake level fluctuations (Maunsell Australia 2006).

Although water quality has been monitored at Lock 9 since the early 1950s, it has not been monitored consistently within Lake Cullulleraine. The only water quality data available are quarterly measurements since 1996 (Australian Water Quality Centre, Bolivar, Adelaide). Over the 5-year period (1996-2001) $\mathrm{pH}$ ranged between 8.1 and 8.6, EC ranged between 460 and $670 \mu \mathrm{S} \mathrm{cm}^{-1}$ (EC ranged between 320 and $560 \mu \mathrm{S} \mathrm{cm}^{-1}$ at Lock 9), turbidity ranged between 45 and 385 NTU, TP between 20 and $150 \mu \mathrm{g} / \mathrm{l}$, and TKN (total Kjeldahl nitrogen) between 450 and $1160 \mu \mathrm{g} / \mathrm{l}$. The maximum lake depth is approximately $3 \mathrm{~m}$, with a mean depth of $2.2 \mathrm{~m}$. There is a general lack of geomorphic or physical data. At the time of coring, the lake edge sustained healthy communities of Typha domingensis and Phragmites australis.

To assess the relation between EC measurements at Lock 9 and those within Lake Cullulleraine, a linear regression was performed on the data (Fig. 2). Although the relation is not strong $\left(r^{2}=0.38\right)$ the trends in the data are similar, i.e., when EC at Lock 9 increases there is a corresponding increase in Lake Cullulleraine. The two outlier data points reflect two temporary periods of very low EC in the main channel that were caused by water released from upstream storage areas.

\section{Methods}

In January 1998, two sediment cores were extracted from the centre of Lake Cullulleraine using a softsediment corer. Both were $48 \mathrm{~cm}$ long. The core site

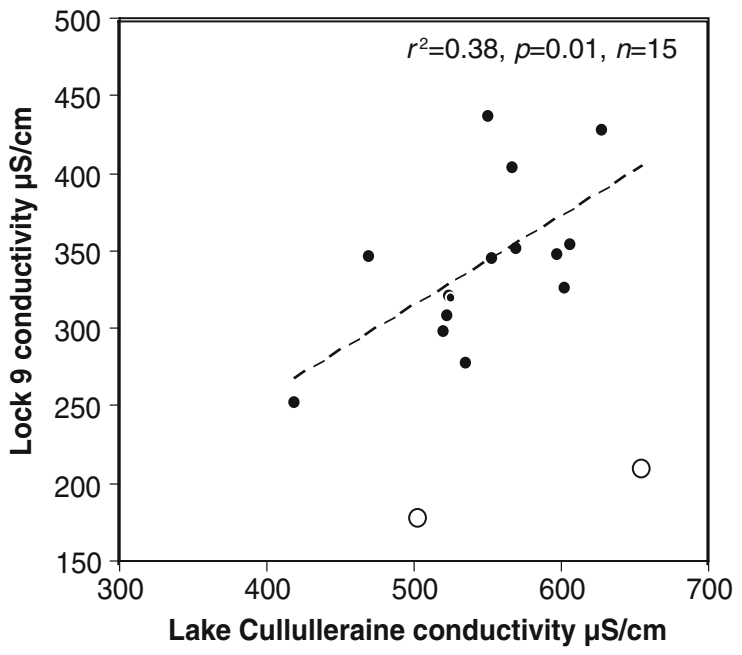

Fig. 2 Linear regression of conductivity measurements at Lock 9 and Lake Cullulleraine. The two hollow circles were excluded from the regression relationship

was chosen after probing the lake sediments and identifying the thickest deposits in the lake. Core 1 was selected for diatom and sediment water content and lithologic analyses, and was sampled at contiguous $1-\mathrm{cm}$ intervals, following vertical extrusion, for water content, organic mater concentration, and diatom analysis. Diatoms were chosen as the primary palaeolimnological tool in this study because of their large abundance, species diversity, and high sensitivity to changes in water chemistry (Moser et al. 1996; Battarbee 1997).

Samples were digested in 10\% HCL and $10 \%$ $\mathrm{H}_{2} \mathrm{O}_{2}$ (Battarbee et al. 2001) to prepare them for diatom counting. From 300 to 500 diatom valves were counted per sample. The minimum count of 300 valves was used because Battarbee et al. (2001) suggests this value to provide a representative count. Broken valves were only counted if the central area was present. Most counting was undertaken using an Olympus BH-2 microscope with a Nomarski differential interference contrast component. The primary diatom floras consulted were Krammer and LangeBertalot (1986, 1988, 1991a, b), supplemented by Foged (1978), Germain (1981), Archibald (1983), Gasse (1986), and John (1983).

Because of the known young age of the wetland, ${ }^{210} \mathrm{~Pb}$ dating was employed to derive age-depth estimates for the Lake Cullulleraine core. Six samples were measured: $0,8,16,25,32$, and $40 \mathrm{~cm}$. They 
were analysed at the Australian Nuclear Science and Technology Organisation. Atmospherically derived, unsupported ${ }^{210} \mathrm{~Pb}$ was estimated from total ${ }^{210} \mathrm{~Pb}$ activity minus the supported ${ }^{210} \mathrm{~Pb}$ activity, the latter derived from decay of in situ ${ }^{226} \mathrm{Ra}$. The activity of total ${ }^{210} \mathrm{~Pb}$ was determined from ${ }^{210} \mathrm{Po}$ activity, with which it is assumed to be in secular equilibrium, using alpha spectrometry (Octete Alphaspectrometry System). Given the linear relationship between depth and excess ${ }^{210} \mathrm{~Pb}\left(r^{2}=0.96\right)$ in the Lake Cullulleraine record, the constant initial concentration (CIC) model (Krishnaswamy et al. 1971) was used to derive age-depth relationships (Fig. 3). The CIC model is most appropriate in lake basins that have a small catchment to lake area ratio and have accumulated sediments at a constant rate. Despite the fact that the very large Murray River Basin sustains the lake, these conditions appeared to have been met. The ${ }^{210} \mathrm{~Pb}$ date for the base of the Lake Cullulleraine sediment was close to the known age of the wetland.

A quantitative EC reconstruction was derived using a 90-sample conductivity data set developed by Tibby et al. (2007). This data set was derived from regular sampling of eight wetlands in the lower Murray River region including Lake Cullulleraine. A simple weighted averaging model with inverse deshrinking produced the best diatom-conductivity model (determined by "leave one-out replacement)" with an RMSEP of $0.318 \log _{10} \mu \mathrm{S} \mathrm{cm}^{-1}$. Other models, including weighted averaging with statistical downweighting of species with broad tolerance and weighted averaging partial least squares (WA-PLS) did not perform as well. The degree of (dis)similarity between the fossil and modern samples was assessed using analogue matching techniques with squared chord distance as the dissimilarity measure, determined using C2 version 1.4.3 (Juggins 2003). These reconstructed values and trends were then compared to measured EC from both Lock 9 and Morgan, with the records extending to 1952 at Lock 9 and 1938 at Morgan. Although Morgan is approximately $450 \mathrm{~km}$ downstream from Lock 9/Lake Cullulleraine, Fig. 2 shows that trends are similar between the two sites, with conductivity amplified at Morgan, due to evaporative concentration and lack of inflows. Although the comparisons between inferred and measured EC are not direct, due to site separation, the differences between Lake Cullulleraine and Lock 9/Morgan should be minimal due to the lakes permanent connection to the channel and lack of other external influences (e.g. multiple, variable inflows).

\section{Results}

\section{Lithostratigraphy}

The 48-cm core consisted of two distinct types of sediment. The surface to $46 \mathrm{~cm}$ was dark greenishgrey mud, while $46-48 \mathrm{~cm}$ was gravelly, coarse sand. The transition between the sediment types was very sharp, as were the changes in water content and organic matter content. Between 0 and $46 \mathrm{~cm}$, water content ranged between 60 and $75 \%$, while between 46 and $48 \mathrm{~cm}$ it was $<20 \%$. The shift in organic

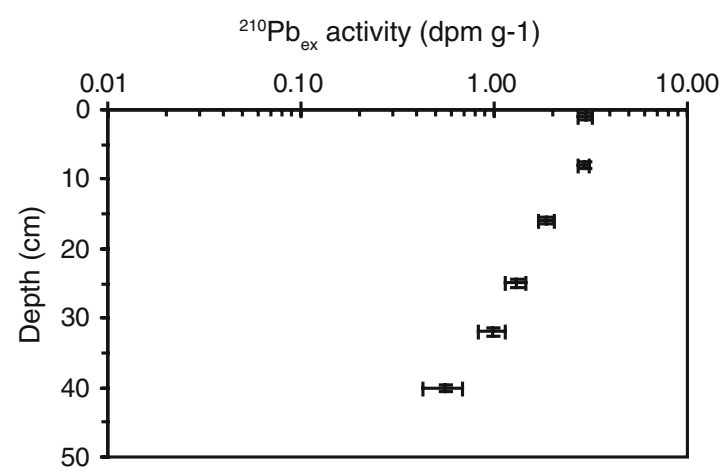

Fig. 3 a Depth verses excess ${ }^{210} \mathrm{~Pb}\left({ }^{210} \mathrm{~Pb}\right.$ ex $)$ in the Lake Cullulleraine core. b Age-depth relationship in the Lake Cullulleraine core derived from a. The solid line indicates the

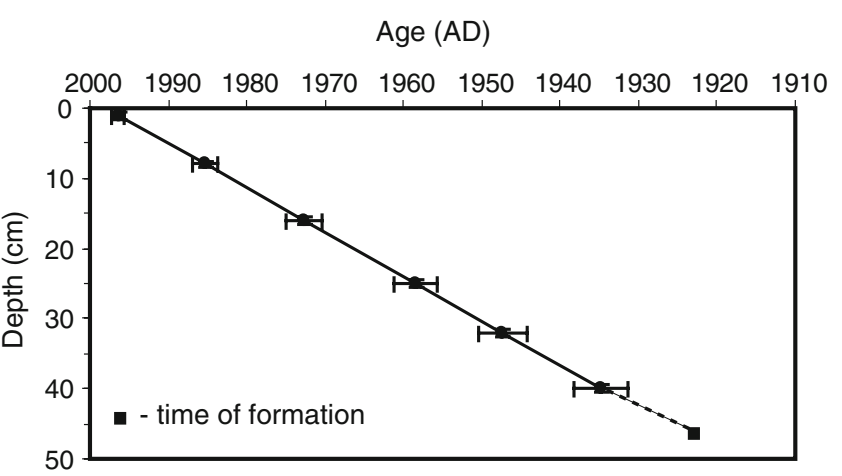

sedimentation rate derived from the ${ }^{210} \mathrm{~Pb}_{\mathrm{ex}}$ data, while the dashed line shows the rate inferred between the basal ${ }^{210} \mathrm{~Pb}_{\mathrm{ex}}$ sample and the time of lake formation 
matter content was not as marked, but was greater in the mud section (mean 25\%) than the base of the core (mean 12\%).

\section{Chronology}

The excess ${ }^{210} \mathrm{~Pb}$ activity profile was essentially monotonic (Fig. 3), unprecedented in Murray River wetlands where changing sediment sources have caused problems for ${ }^{210} \mathrm{~Pb}$ dating. The estimated sedimentation rate is $0.632 \pm 0.05 \mathrm{~cm} /$ year. The sediment at $40 \mathrm{~cm}$ depth was estimated to be $\sim 63$ years old (i.e. AD 1935). Extrapolation of the mean sedimentation rate to the base of the core $(48 \mathrm{~cm})$ suggests basal sediments were deposited in the early 1920s, just prior to initial lake filling in 1926.

Diatom analysis

The Lake Cullulleraine core has well defined diatom zones with distinct contrast between the top and bottom
(Fig. 4). CONISS (Grimm 1987) clustering was used to separate fossil diatom assemblages into five zones; $35-32 \mathrm{~cm}, 32-20 \mathrm{~cm}, 20-10 \mathrm{~cm}, 10-5 \mathrm{~cm}$, and $5-0 \mathrm{~cm}$. Although the entire core was sampled, diatoms were only present from $35 \mathrm{~cm}$ to the surface in any abundance. In all samples between 45 and $35 \mathrm{~cm}$ depth, the only diatoms were aerophilous types, mainly Pinnularia borealis, Hantzschia amphioxys and Luticola mutica, in abundances too low for effective counting.

Zone $5(35-32 \mathrm{~cm})$ : Zone 5 is dominated by Aulacoseira subborealis, which is present at $>60 \%$ in all samples. The next most common taxon is Staurosira construens var. venter, which is present at $9 \%$ at $35 \mathrm{~cm}$, increasing to $14 \%$ at $32 \mathrm{~cm}$. Minor taxa present at $<2 \%$ include Cocconeis placentula, Epithemia sorex and Epithemia adnata.

Zone $4(32-20 \mathrm{~cm})$ : The most obvious features of this zone are an increase in $S$. construens var. venter and a corresponding decrease in A. subborealis. At the top of this zone, A. subborealis has decreased to $<2 \%$ while the abundance of $S$. construens var.

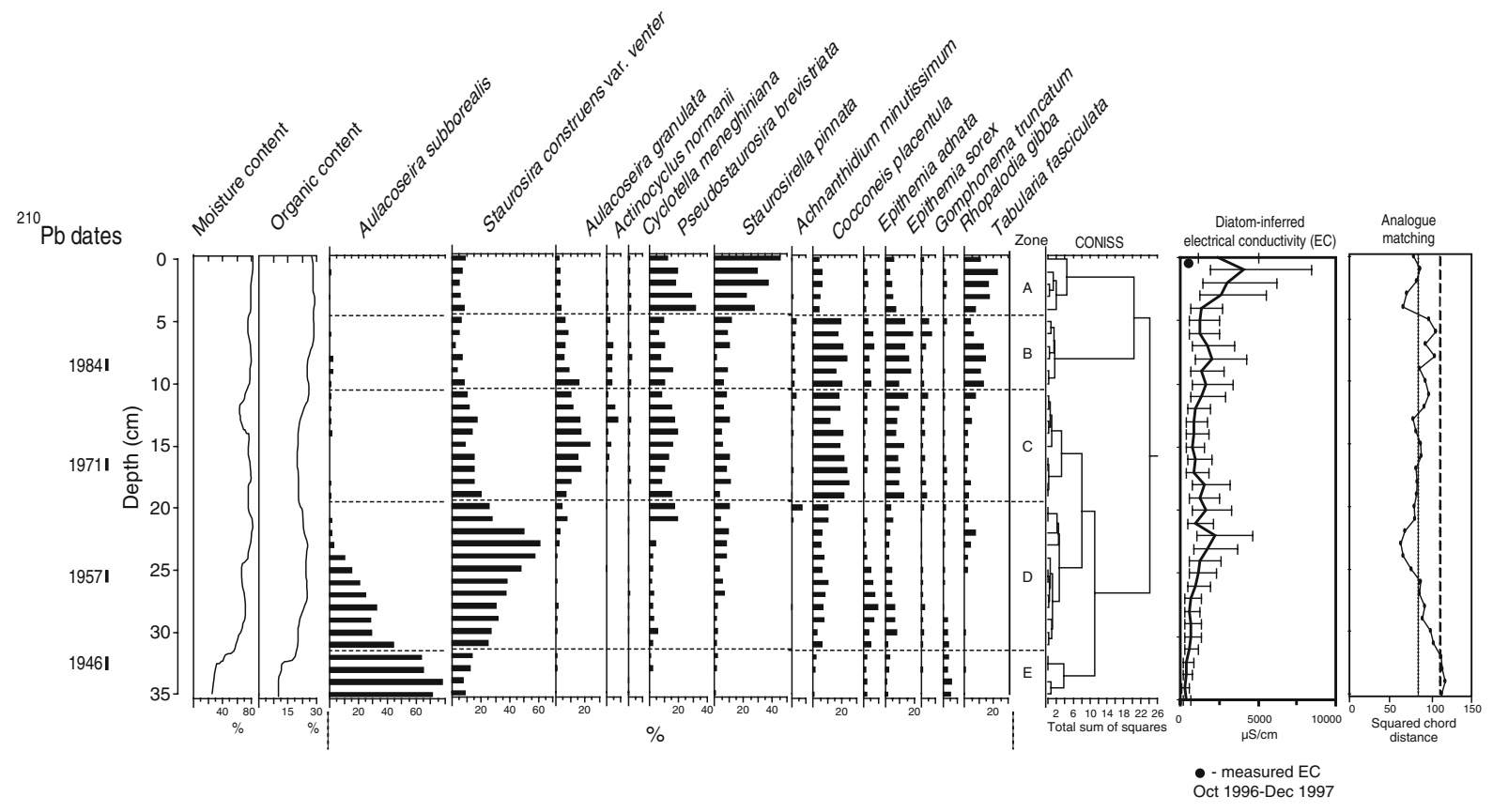

Fig. 4 Lake Cullulleraine diatom fossil record. Also shown is the diatom-inferred conductivity derived from Tibby et al. (2007) data set and the (squared chord distance-SCD) degree of dissimilarity between each sample and the most similar sample in the data set. Also shown is the average measured EC from October 1996 to December 1997, when the core was collected
(Gell et al. 2002).The vertical dotted and dashed lines represent the 5th and 10th percentile of distributions, respectively, in Tibby et al. (2007). Note that samples with SCDs lower than the 10th percentile have good analogues in the modern data set (Simpson 2007) 
venter peaks at $23 \mathrm{~cm}(60 \%)$ and then decreases towards the top of the zone with an abundance of $25 \%$ at $20 \mathrm{~cm}$. As the abundance of $S$. construens var. venter decreases, it is predominantly replaced by another facultative planktonic taxon, Pseudostaurosira brevistriata, which has an abundance of $17 \%$ at $20 \mathrm{~cm}$. Other changes include small increases in the littoral taxa Epithemia sorex, Cocconeis placentula, and the facultative planktonic Staurosira pinnata.

Zone 3 (20-10 cm): Aulacoseira subborealis decreases to an average of $<1 \%$ abundance in this zone. S. construens var. venter also decreases gradually in this zone until it reaches an abundance of $10 \%$ at $11 \mathrm{~cm}$. These two taxa are replaced by taxa of three different ecological preferences (littoral, facultative planktonic and planktonic). Within the littoral taxa, Cocconeis placentula and Epithemia sorex increase in abundance, to an average of 18.3 and $11.1 \%$, respectively, with the increase occurring early in the zone and then representation remaining relatively constant. Gomphonema truncatum increases to an average abundance of $3 \%$, compared to $<1 \%$ in zone 4. Pseudostaurosira brevistriata, a facultative planktonic taxon, decreases at the beginning of the zone, before increasing again, peaking at $20 \%$ abundance at $14 \mathrm{~cm}$ and then decreasing to $<10 \%$ at the top of the zone. Staurosirella pinnata abundance remains unchanged from zone 4. Planktonic taxa, primarily Aulacoseira granulata, increase substantially in this zone. Aulacoseira granulata peaks in abundance at $15 \mathrm{~cm}$ with $23 \%$ of the total assemblage, before gradually decreasing again towards the top of the zone $(11 \mathrm{~cm})$ where it accounts for $10 \%$ of the assemblage. On average, A. granulata explains $14 \%$ of the diatom assemblage in zone 3 . In regard to other planktonic taxa, Actinocyclus normanii also increases, from $<0.5 \%$ in zone $4-2.2 \%$ in this zone, while Cyclotella meneghiniana has fairly consistent representation.

Zone $2(10-5 \mathrm{~cm})$ : There are three major changes in this zone: a decrease in both Aulacoseira granulata and Staurosira construens var. venter, and an increase in Tabularia fasciculata. Aulacoseira granulata abundance decreases to an average of $8 \%$ from its average of $14 \%$ in the previous zone. Staurosira construens var. venter continues the decline shown in zone 3 , decreasing to an average of $<10 \%$. Tabularia fasciculata sharply increases in abundance in this zone, reaching a peak of $14 \%$ at $8 \mathrm{~cm}$.
Zone $1(5-0 \mathrm{~cm})$ : There is a sharp boundary between zone 1 and zone 2 . There is a simultaneous increase in S. pinnata and P. brevistriata. Staurosirella pinnata is the dominant taxon, accounting for an average of $32 \%$ of the diatom assemblage across the zone, and shows an increasing trend toward the surface. Conversely, P. brevistriata shows a decreasing trend toward the surface. Planktonic taxa decrease in this zone, with A. granulata abundance falling from an average of $11.2 \%$ in zone 2 to $<3 \%$, and $A$. normanii abundance falling to $<1 \%$ from $2 \%$ in zone 2. The two principle littoral taxa, C. placentula and E. sorex, decrease markedly in this zone (averages of 4.2 and $5 \%$, respectively), but because of the increase in T. fasciculata, total representation of littoral taxa changes little $(33.6 \%$ in this zone compared to $35 \%$ in zone 2).

Salinity reconstruction, analogue matching and comparison to historical measured values

The quantitative EC reconstruction is shown in Fig. 4. Most samples in the core (32 of 35) had a squared chord distance to the nearest sample in Tibby et al. (2007) lower than the 10th percentile of distributions in the data set, with fifteen of these falling below the 5th percentile of distributions.

Inferred EC for Lake Cullulleraine range between $700 \mu \mathrm{S} \mathrm{cm}^{-1}$ and more than $4,000 \mu \mathrm{S} \mathrm{cm}^{-1}$, with an increasing trend from 1940 to the early 1960s, stabilisation through the 1960s and 1970s, and then a rapid increase in the 1990s. Measured EC ranged from 180 to $890 \mu \mathrm{S} \mathrm{cm}^{-1}$ at Lock 9 and 160$1,600 \mu \mathrm{S} \mathrm{cm}^{-1}$ at Morgan (Fig. 5). Lock 9 and Morgan EC records show an increasing trend in the 1960 s and 1970s, with both records peaking in the 1970s, and general declines in EC from the late 1970s to the present.

\section{Discussion}

The diatom record from Lake Cullulleraine provides a detailed, high-resolution record of changes in a lower Murray River aquatic ecosystem since river regulation. There are distinct changes in the diatom community over the length of the core. As well as facilitating interpretation, this pattern of species 


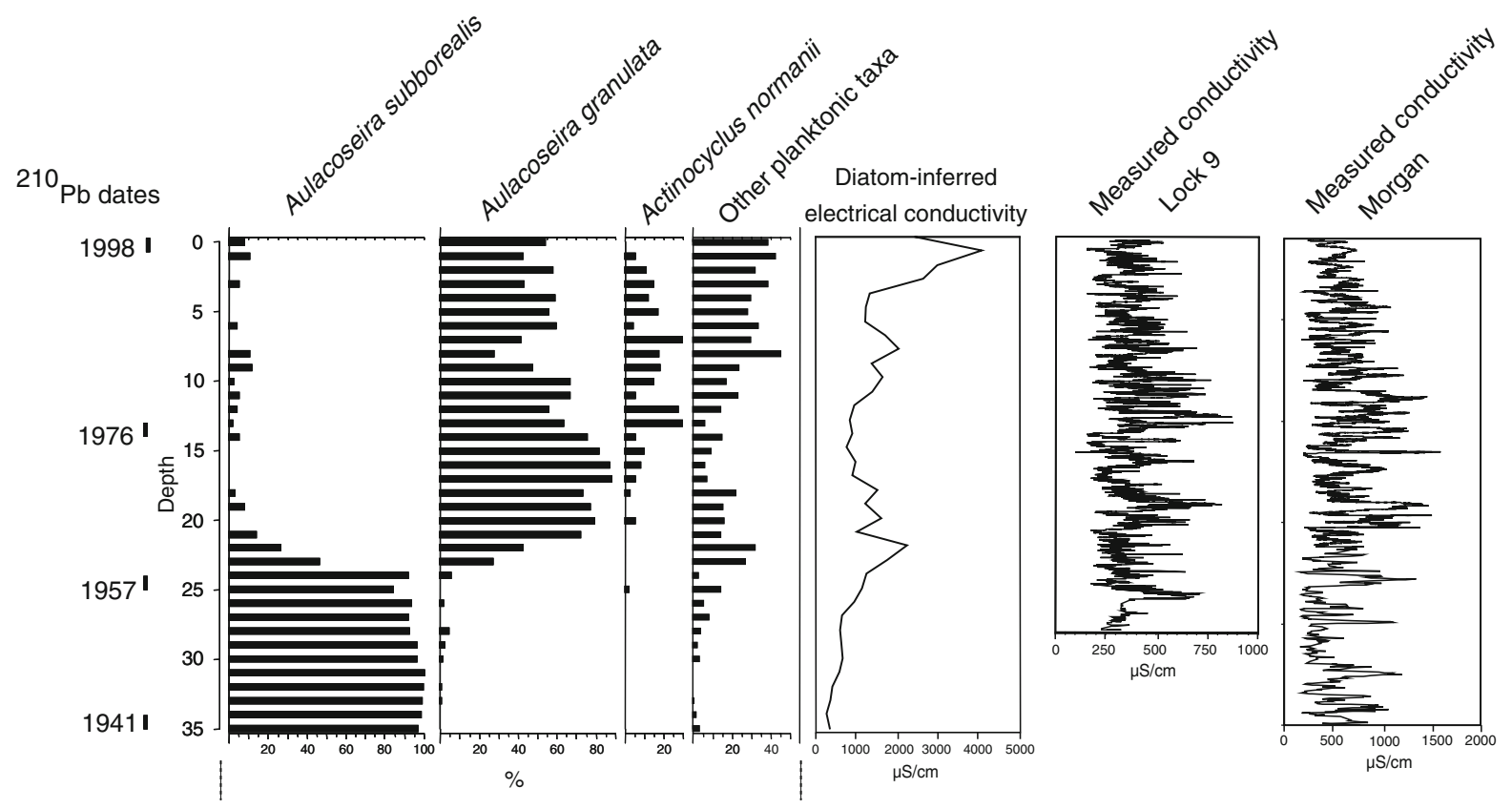

Fig. 5 Selected fossil planktonic diatom taxa plotted against inferred EC and measured EC at Lock 9 and Morgan over time

presence suggests that lake sedimentation has been relatively undisturbed (minimal bioturbation).

${ }^{210} \mathrm{~Pb}$ dating yielded a sedimentation rate of $0.632 \pm 0.05 \mathrm{~cm} /$ year for the top $40 \mathrm{~cm}$, which apparently accumulated at a constant rate. Extrapolation of this rate to the base of the core $(48 \mathrm{~cm})$ suggests that basal sediments were deposited approximately at the time of lake inundation (1926), with permanent wetland conditions prevailing thereafter. Interpretation of this change as a transition from an ephemeral wetland to a permanent wetland is, however, complicated by the virtual absence of diatoms between 48 and $36 \mathrm{~cm}$. The few valves $(<5$ per slide transect) present are badly preserved, and are mostly from aerophilous and benthic taxa, rather than the planktonic and epiphytic types that dominate the upper $36 \mathrm{~cm}$. Sediment records in newly created lakes (such as reservoirs), often fail to preserve abundant diatoms for at least 10 years. Burrinjuck Reservoir (southern Australia) has few planktonic diatoms in sediments deposited during the first 20 years of lake development, with the sediment containing only sparse, aerophilous taxa, similar to the pattern observed in other studies (Tibby 2001 and references therein). Tibby (2001) suggested that this is due to a water column silica deficit, with sediment preferentially taking up silica. In the early development of both Lake Cullulleraine and Burrinjuck Reservoir, it is likely that there was planktonic diatom production, but cells probably dissolved before they were incorporated into the sediment.

The relationship between diatom-inferred electrical conductivity (DI-EC) and measured conductivity from the limited data for Lake Cullulleraine $(n=6)$ (Gell et al. 2002) and the longer data set from the River Murray is poor (Figs. 4, 5). For example, the period of highest inferred EC is the 1990s, while the measured EC in the River at that time was notably lower than the maxima recorded in the late 1970s and early 1980s. Similarly, a peak in DI-EC in the early 1960s had no associated peak in measured conductivity. Measured conductivity at both Lock 9 and Morgan corroborates recent evidence compiled by CSIRO (2003), which showed that rapid increases in conductivity in the 1960s and 1970s have halted, and even reversed throughout much of the Basin, mainly due to salt interception schemes. Importantly, analogue matching indicates that the majority of samples had good analogues in the Tibby et al. (2007) data set. Hence, a poor match between the modern and fossil samples is unlikely to explain the poor relationship between conductivity trends recorded at 
Lock 9 and those inferred from Lake Cullulleraine diatoms. These observations are similar to those made by Reid and Ogden (2009) in a survey of Murray Basin wetlands. They found that diatom composition was less influenced by water quality than reach position, hydrology and macrophyte cover. Given their conclusions, we assess potential reasons for a lack of success in the salinity reconstruction, particularly whether the diatom flora reflects drivers that are more influential than salinity in this environment. We also consider, using published data, whether the EC optima and tolerances derived by Tibby et al. (2007) for key taxa in the Lake Cullulleraine record are accurate.

One of the most important changes in the Lake Cullulleraine record is the shift between Aulacoseira subborealis (dominant in zone 4) and the facultative planktonic Staurosira construens var. venter, the dominant taxon in zone 3 , which is also associated with substantial increases in inferred conductivity. Given the significance of this change, it is important to consider the ecology of these taxa and what factors, other than salinity, might explain this shift.

Investigations into the autecology of A. subborealis are complicated by its recent description and, more importantly, its relatively poor representation in datasets outside of Australia (Denys et al. 2002). However, within Australia, A. subborealis is strongly represented in the EC calibration set applied in this study (optimum of $432 \mu \mathrm{S} \mathrm{cm}^{-1}$ derived from 37 samples with a maximum abundance of $16 \%$ ) and has otherwise been demonstrated to be a key component of the plankton flora of the Murray River (Tibby and Reid 2004). Figure 6 shows the pattern of this taxon's representation in four sites along the lower Murray River (including Lake Cullulleraine). Mundic, Tanyaka and Sinclair's Flat are all natural wetlands with permanent connection to the main channel (Fluin and Gell 2008). All three fossil diatom records represent a longer time period than Lake Cullulleraine; Mundic is $\sim 2,700$ years, Tanyaka is $\sim 3,500$ years and Sinclair's Flat is undated, but magnetic susceptibility correlation with nearby sites suggest the record covers $\sim 1,800$ years. These records illustrate both pre-regulation and pre-settlement presence and abundance of A. subborealis, with all three records clearly showing a sudden appearance of the taxon immediately succeeding river regulation (occurring regionally between 1920 and 1940), followed by a steady decline towards present. This pattern suggests that the decline in A. subborealis in Lake Cullulleraine is not due to autochthonous processes, but rather represents a regional decline in the planktonic taxon's abundance in the river channel following river regulation.

Staurosira construens var. venter is better represented than $A$. subborealis in transfer functions outside Australia and has a wide tolerance with respect to a number of environmental variables. Table 1 summarises optima derived from studies in which this taxon is well represented. Table 1 indicates that if these transfer functions differ from one another appreciably and would yield a range of inferences for $\mathrm{pH}, \mathrm{EC}$ and TP if applied to the Lake Cullulleraine record. It is also evident that the EC optimum of $1,212 \mu \mathrm{S} \mathrm{cm}^{-1}$, from 42 samples with a maximum abundance of $65 \%$, derived by Tibby et al. (2007), is substantially higher than the optimum for A. subborealis $\left(432 \mu \mathrm{S} \mathrm{cm}^{-1}\right)$, and is generating the increase in inferred salinity.

Despite sparse and inconsistent ecological data on A. subborealis and Staurosira construens var. venter, some conclusions can be drawn about water quality in Lake Cullulleraine. These taxa indicate that $\mathrm{pH}$ and perhaps nutrient concentrations were slightly lower in the period 1940-1960 than in the present lake (Fluin 2002), with both taxa most abundant in mesotrophic, neutral waters, particularly within the basin (Tibby et al. 2003, 2007; Tibby and Reid 2004). Hence, it appears unlikely that changes in $\mathrm{pH}$ or nutrient status explain the increase in $S$. construens var. venter that commenced in the late 1940s. Despite the different habitat preferences of these taxa, it is similarly unlikely that changes in water level explain this change since Lake Cullulleraine's level is artificially maintained.

As much of the existing ecological data for S. construens var. venter is contradictory, information from taxa co-occurring in zone $\mathrm{D}$ can be used to refine environmental reconstructions. Cocconeis placentula, Epithemia sorex and Epithemia adnata are almost certainly derived from the littoral zone of the lake, as they are epiphytes (Sonneman et al. 2001) and are rarely reported in plankton surveys of the River Murray (Hötzel and Croome 1996; Fluin 2002; Tibby and Reid 2004). Therefore, their increasing presence most likely represents an increase in fringing/submerged vegetation. Hence, the early changes in the Lake Cullulleraine diatom community may 

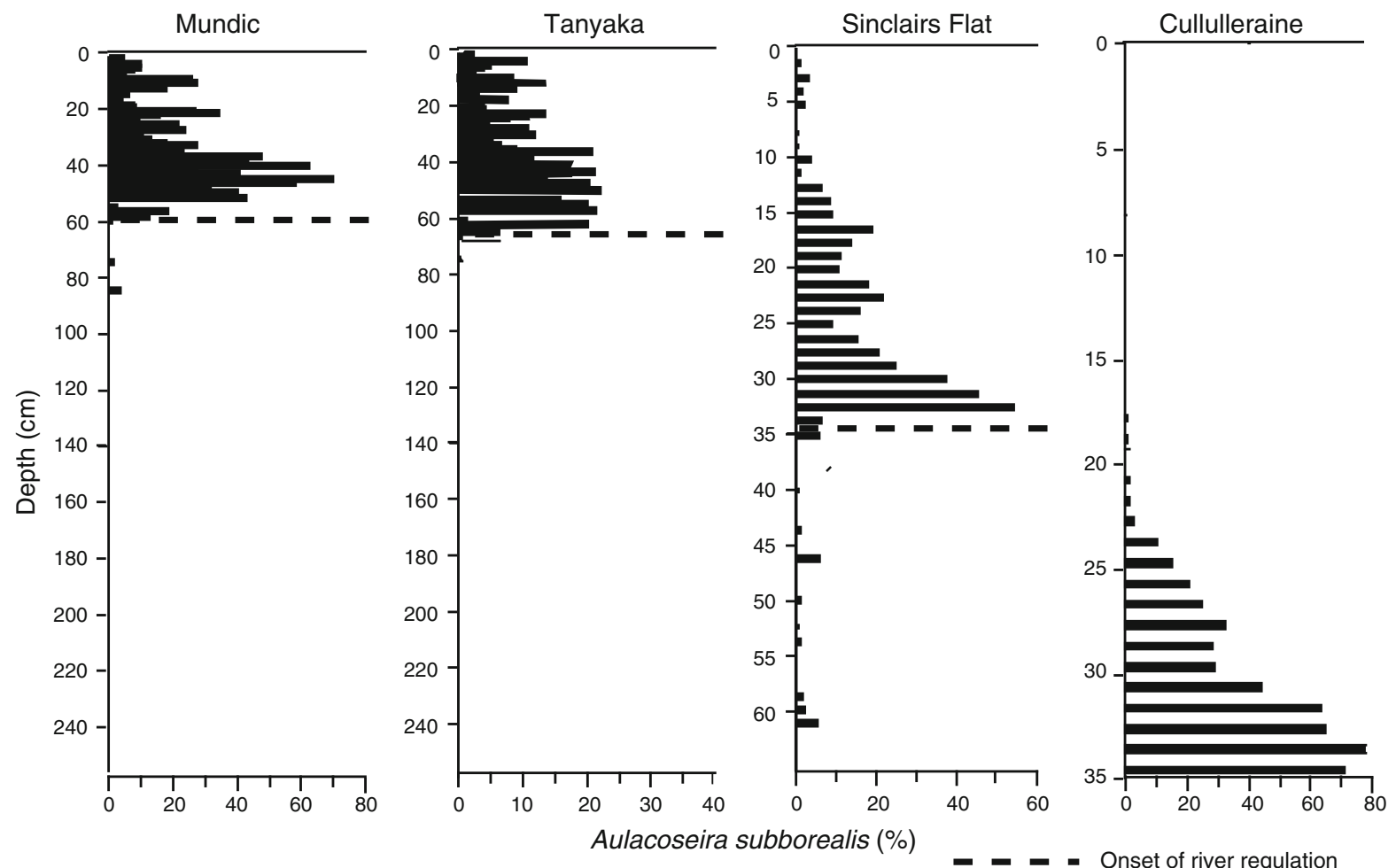

Fig. 6 Spatial pattern of Aulacoseira subborrealis presence and abundance in multiple lower Murray River wetlands. The dashed line indicates the approximate timing of river regulation

Table 1 Comparison of published $\mathrm{pH}$, EC and TP optima for Staurosira construens var. venter

\begin{tabular}{lccc}
\hline Study & $\mathrm{pH}$ & $\begin{array}{l}\mathrm{EC} \\
\left(\mu \mathrm{S} \mathrm{cm} \mathrm{cm}^{-1}\right)\end{array}$ & $\begin{array}{l}\mathrm{TP} \\
(\mu \mathrm{g} / \mathrm{l})\end{array}$ \\
\hline $\begin{array}{l}\text { Bennion (1993) } \\
\text { Cameron et al. (1999) }\end{array}$ & 6.1 & & 71.1 \\
Charles and Whitehead (1986) & 7.3 & & \\
Dixit et al. (1999) & 7.3 & & \\
Fluin (2002) & 6.9 & & \\
Fritz et al. (1993) & & 3,590 & \\
Gell (1997) & & 4,340 & \\
Reavie et al. (1995) & & & \\
Reed (1998) & & 830 & \\
Stevenson et al. (1991) & 6.2 & & \\
Tibby (2004) & & & \\
Tibby et al. (2003) & 7.7 & & \\
Tibby et al. (2007) & & 1,212 & \\
\hline
\end{tabular}

simply be an artefact of lake ontogeny. It appears that in the early stages of lake development, planktonic diatoms dominated due to a lack of aquatic vegetation, but as macrophytes proliferated, opportunistic diatoms such as $S$. construens var. venter increased in abundance.

As a consequence of the possible overriding influence of lake development, it is useful to consider the trends solely in the plankton community. Hence, a record derived from purely planktonic diatoms is shown in Fig. 5 along with measured EC from Lock 9 and Morgan. In this diagram, the decrease in $A$. subborealis is contemporaneous with an increase in the planktonic Aulacoseira granulata, which is the most abundant modern taxon in the River Murray (Hötzel and Croome 1996). This change is commensurate with similar patterns in the records of Mundic, Tanyaka and Sinclair's Flat where A. granulata replaces A. subborealis (Fluin and Gell 2008), again suggesting that this is a regional, river-derived change, rather than an autochthonous lake process. The switch from A. subborealis to A. granulata in all of these records occurs at a time of monitored increased salinity in the river channel (Fig. 5). Hence, this change could be attributed to conductivity, 
although A. subborealis has an higher EC optimum than A. granulata [320 vs. $251 \mu \mathrm{S} \mathrm{cm}^{-1}$ (Tibby and Reid 2004) or 467 vs. $398 \mu \mathrm{S} \mathrm{cm}^{-1}$ (Tibby et al. 2007)].

From the late 1960s, there is a substantial decrease in $S$. construens var. venter, with a corresponding increase in other facultative planktonic taxa such as Psuedostaurosirella brevistriata and Staurosirella pinnata and the littoral taxa Cocconeis placentula and Epithemia sorex. The abundance of littoral diatoms was at its highest during that time, suggesting that it was the period of maximum aquatic vegetation extent. Cocconeis placentula, a littoral taxon, can tolerate elevated conductivity [optimum $17,680 \mu \mathrm{S} \mathrm{cm}^{-1}$ based on 118 occurrences (Gell 1997)], but can be equally abundant in very fresh waters. Gasse et al. (1995a, b) published an EC optimum for this taxon of $467 \mu \mathrm{S} \mathrm{cm} \mathrm{cm}^{-1}$ based on 74 occurrences. There may well be an association between measured EC (Fig. 5) and C. placentula, as EC increased in the 1960s and then decreased from the late 1970 s to the present.

The next major change in the diatom community occurs in the top $5 \mathrm{~cm}$ of sediment, representing approximately the time period 1988-1998. Staurosirella pinnata and Pseudostaurosira brevistriata increase to maxima during this phase, while $A$. granulata, C. placentula, and E. sorex decrease. Interpreting this recent variability is just as problematic as interpreting changes in the earlier phases of the fossil record as the primary taxa display wide tolerances to key chemical variables. Tables 2 and 3 summarise the published $\mathrm{pH}, \mathrm{EC}$ and TP optima for $S$. pinnata and $P$. brevistriata from studies in which these taxa were abundant and well represented. As with $S$. construens var. venter, these taxa do not have specific ecological preferences. Interestingly, during this time period there are no commensurate shifts in the plankton-only diagram (Fig. 5), which may suggest that these recent changes reflect in-lake processes.

\section{Conclusions}

This study demonstrated there is little correspondence between reconstructed water quality values (absolute terms or data trends) from a permanently connected riverine wetland (Lake Cullulleraine), and measured water quality values in the source stream (River
Table 2 Comparison of published $\mathrm{pH}$, EC and TP optima for Staurosirella pinnata

\begin{tabular}{|c|c|c|c|}
\hline Study & $\mathrm{pH}$ & $\begin{array}{l}\mathrm{EC} \\
\left(\mu \mathrm{S} \mathrm{cm}{ }^{-1}\right)\end{array}$ & $\begin{array}{l}\mathrm{TP} \\
(\mu \mathrm{g} / 1)\end{array}$ \\
\hline Agbeti (1992) & & & 26.5 \\
\hline Bennion (1994) & & & 94 \\
\hline Bennion et al. (1996) & & & 194 \\
\hline Cameron et al. (1999) & 7.13 & & \\
\hline Dixit and Smol (1994) & 7.9 & & 14.4 \\
\hline Dixit and Smol (1995) & 5.8 & & \\
\hline Dixit et al. (1999) & 7.6 & & 14 \\
\hline Fluin (2002) & 8.3 & & \\
\hline Fritz et al. (1993) & & 4,340 & \\
\hline Gasse et al. $(1995 a, b)$ & 7.97 & 144 & \\
\hline Gell (1997) & & 5,721 & \\
\hline Reavie et al. (1995) & & & 21.8 \\
\hline Stevenson et al. (1991) & 6.3 & & \\
\hline Tibby (2004) & & & 17 \\
\hline Tibby et al. (2003) & 8.2 & & \\
\hline Tibby et al. (2007) & & 3,065 & \\
\hline
\end{tabular}

Table 3 Comparison of published $\mathrm{pH}$, EC and TP optima for Pseudostaurosira brevistriata

\begin{tabular}{llll}
\hline Study & $\mathrm{pH}$ & $\begin{array}{l}\mathrm{EC} \\
\left(\mu \mathrm{S} \mathrm{cm} \mathrm{cm}^{-1}\right)\end{array}$ & $\begin{array}{l}\mathrm{TP} \\
(\mu \mathrm{g} / \mathrm{l})\end{array}$ \\
\hline $\begin{array}{l}\text { Agbeti (1992) } \\
\text { Bennion (1994) }\end{array}$ & & $\begin{array}{l}34.48 \\
95.7\end{array}$ \\
$\begin{array}{l}\text { Bennion et al. (1996) } \\
\text { Cameron et al. (1999) }\end{array}$ & 7.08 & & 180 \\
$\begin{array}{l}\text { Dixit and Smol (1994) } \\
\text { Dixit et al. (1999) }\end{array}$ & 8.0 & & 12.6 \\
Fluin (2002) & 7.7 & & 13 \\
Fritz et al. (1993) & 8.3 & & \\
Gasse et al. (1995a, b) & 7.82 & 575 & 12.2 \\
Gell (1997) & & 2,802 & \\
Reavie et al. (1995) & & & \\
Reed (1998) & & 1,550 & \\
Reid (1997) & & & \\
Stevenson et al. (1991) & 6.5 & & \\
Tibby (2004) & & & \\
Tibby et al. (2003) & 8.2 & & \\
Tibby et al. (2007) & & 633 & \\
\hline & & & \\
\hline
\end{tabular}

Murray). There may be two reasons for the lack of correlation. First, Lake Cullulleraine and a number of other River Murray wetlands, support a littoral 
diatom flora characterised by taxa such as Cocconeis placentula, Aulacoseira granulata, Staurosirella pinnata, Staurosira construens varieties and Pseudostaurosira brevistriata that have wide ecological tolerances (Gell 1997; Reid 1997; Tibby 2000; Gell et al. 2002; Tibby et al. 2003; Tibby and Reid 2004; Fluin et al. 2007). Fossil records dominated by nonplanktonic taxa are not well suited to quantitative water quality reconstructions (Sayer 2001; Bennion et al. 2001). Second, despite the direct connection between the Murray River and Lake Cullulleraine, autochthonous processes (e.g. the establishment and development of aquatic vegetation) serve to confound the influence of the River on Lake Cullulleraine. This may also hold true for many other wetlands that, as a result of river regulation, are now permanently connected to the River Murray, whereas they once would have experienced wet and dry regimes. This finding is important since records from such wetlands are increasingly used to infer changes in river history (Gell et al. 2002, 2007).

Caution should be used when interpreting diatom records (particularly in a quantitative manner) in this environment. Nevertheless, palaeoecological techniques do reveal patterns of limnological change over various timescales in the Murray-Darling Basin. The Lake Cullulleraine fossil record demonstrates this potential, particularly if interpretation is focused on the planktonic taxa, by providing evidence of land use impacts, for which there are not historical records. This study highlights the need to validate findings of diatom records from individual riverine wetlands through development of multiproxy palaeoecological data at individual sites and replication across multiple sites.

Acknowledgments This research was undertaken while JF held an Australian Postgraduate Award and was partially supported by Monash University's Strategic University Research Fund and the Australian Nuclear Science and Technology Organisation's Human Activity and Climate Variability Project.

\section{References}

Agbeti MD (1992) Relationship between diatom assemblages and trophic variables: comparison of old and new approaches. Can J Fish Aquat Sci 49:1171-1175. doi: $10.1139 / \mathrm{f} 92-131$

Archibald REM (1983) The diatoms of the Sundays and Great Fish Rivers in the Eastern Cape province of South Africa. Cramer, Vaduz
Battarbee RW (1997) Freshwater quality, naturalness and palaeolimnology. In: Boon PJ and Howell DL (eds) Freshwater quality: defining the indefinable?, The Stationery Office (1997), pp 155-171 (Chapter 14)

Battarbee RW, Jones VJ, Flower RJ, Cameron NG, Bennion H, Carvalho L, Juggins S (2001) Diatoms. In: Stoermer EF, Birks HJB, Last WM (eds) Tracking environmental change using lake sediments, vol. 3, terrestrial, algal and siliceous indicators. Kluwer, Dordrecht, pp 155-202

Bennion H (1993) A diatom-phosphorus transfer function for eutrophic ponds in south-east England. Unpublished $\mathrm{PhD}$ thesis, University College London

Bennion H (1994) A diatom-phosphorus transfer function for shallow, eutrophic ponds in southeast England. Hydrobiologia 275(276):391-410

Bennion H, Juggins S, Anderson NJ (1996) Predicting epilimnetic phosphorus concentrations using an improved diatom-based transfer function and its application to lake eutrophication management. Environ Sci Technol 30:2004-2007. doi:10.1021/es9508030

Bennion H, Appleby PG, Phillips GL (2001) Reconstructing nutrient histories in the Norfolk Broads, UK: implications for the role of diatom-total phosphorus transfer functions in shallow lake management. J Paleolimnol 26:181-204. doi:10.1023/A:1011137625746

Cameron NG, Birks HJB, Jones VJ, Berge FJ, Flower RJ, Garcia J, Kawecka B, Koinig KA, Marchetto A, SánchezCastillo P, Schmidt R, Solovieva N, Toro M (1999) Surface-sediment and epilithic diatom $\mathrm{pH}$ calibration sets for remote European mountain lakes (AL:PE project) and their comparison with the Surface Waters Acidification Programme (SWAP) calibration set. J Paleolimnol 22:291-317. doi:10.1023/A:1008025928509

Charles DF, Whitehead DR (1986) The PIRLA project: palaeoecological investigations of recent lake acidification. Hydrobiologia 143:13-20. doi:10.1007/BF00026639

Crabb P (1993) The Murray Darling basin: a resource at risk. Longman Cheshire, Melbourne

CSIRO (2003) Is the river Murray water quality deteriorating? A salinity perspective. CSIRO Land and Water, Canberra

Denys L, Muylaert K, Krammer K, Joosten T, Reid M, Rioual P (2003) Aulacoseira subborealis stat. nov. (Bacillariophyceae): a common but neglected plankton diatom from eutrophic waters. Nova Hedwigia 77:407-427

Dixit SS, Smol JP (1994) Diatoms as indicators in the environmental monitoring and assessment program-surface waters (EMAP-SW). Environ Monit Assess 31:275-306

Dixit SS, Smol JP (1995) Diatom evidence of past water quality changes in Adirondack seepage lakes (New York, U.S.A). Diatom Res 10(1):113-129

Dixit SS, Smol JP, Charles DF, Hughes RM, Paulsen SG, Collins GB (1999) Assessing water quality changes in the lakes of the north-eastern United States using sediment diatoms. Can J Fish Aquat Sci 56:131-152. doi:10.1139/ cjfas-56-1-131

Fluin J (2002) A diatom based palaeolimnological investigation of the lower Murray River, south east Australia. Unpublished PhD thesis. Monash University, Australia

Fluin J, Gell PA (2008) Sediment derived scenarios of wetland status and change, the lower Murray River, SA. Final 
Report to the South Australian Murray-Darling Basin Natural Resources Management Board

Fluin J, Haynes D, Gell P, Tibby J, Hancock G (2007) Paleolimnological evidence for the independent evolution of neighbouring terminal lakes, the Murray Darling Basin, Australia. Hydrobiologia 591(1):117-134. doi:10.1007/ s10750-007-0799-y

Foged N (1978) Diatoms in eastern Australia. Cramer, Vaduz

Fritz SC, Juggins S, Battarbee RW (1993) Diatom assemblages and ionic characterisation of lakes of the northern Great Plains, N.A.: a tool for reconstructing past salinity and climate fluctuations. Can J Fish Aquat Sci 50:1844-1856. doi:10.1139/f93-207

Gasse F (1986) East African diatoms: Taxonomy ecological distribution. Cramer, Berlin

Gasse F, Juggins S, BenKhelifa L (1995a) Diatom-based transfer functions for inferring past hydrochemical characteristics of African lakes. Palaeogeogr Palaeocl 117:3154. doi:10.1016/0031-0182(94)00122-O

Gasse F, Juggins S, BenKhelifa L (1995b) Diatom-based transfer functions for inferring past hydrochemical characteristics of African lakes. Palaeogeogr Palaeocli 117:31-54. doi:10.1016/0031-0182(94)00122-O

Gell PA (1997) The development of a diatom data base for inferring lake salinity: towards a quantitative approach for reconstructing past climates. Aust J Bot 45:389-423. doi: 10.1071/BT96036

Gell PA, Sluiter IR, Fluin J (2002) Seasonal and inter-annual variations in diatom assemblages in Murray River-connected wetlands in northwest Victoria, Australia. Mar Freshw Res 53:981-992. doi:10.1071/MF01021

Gell P, Bulpin S, Wallbrink P, Bickford S, Hancock G (2005) Tareena Billabong-A palaeolimnological history of an everchanging wetland, Chowilla Floodplain, lower Murray-Darling Basin. Mar Freshw Res 56:441-456. doi: 10.1071/MF04107

Gell P, Fluin J, Tibby J, Haynes D, Khanum S, Walsh B, Hancock G, Harrison J, Zawadzki A, Little F (2006) Changing fluxes of sediments and salts as recorded in lower River Murray wetlands, Australia. Int Ass Hydrol Sci publication 306:416-424

Gell P, Tibby J, Baldwin D, Little F, Hancock G (2007) The impact of regulation and salinisation on floodplain lakes: the lower River Murray, Australia. Hydrobiologia 591(1):135-146. doi:10.1007/s10750-007-0806-3

Germain H (1981) Flores des diatomées eaux douces et saumâtres. Société Nouvelle des Editions Boubeé, Paris

Hötzel G, Croome R (1996) Population dynamics of Aulacoseira granulata (Ehr.) Simonson (Bacillariophyceae, Centrales), the dominant alga in the Murray River, Australia. Arch Hydrobiol 136:191-215

John J (1983) The diatom flora of the Swan River Estuary western Australia., Bibliotheca Phycologia, vol 64. J. Cramer, Vaduz

Juggins S (2003) C2 user guide. Software for ecological and palaeoecological data analysis and visualisation. University of Newcastle, Newcastle upon Tyne

Krammer K, Lange-Bertalot H (1986) Bacillariophyceae. 1: Teil: Naviculaceae. Gustav Fischer Verlag, Jena

Krammer K, Lange-Bertalot H (1988) Bacillariophyceae. 2: Teil: Bacillariaceae, Epthimiaceae, Surirellaceae. Gustav Fischer Verlag, Jena
Krammer K, Lange-Bertalot H (1991a) Bacillariophyceae. 3: Centrales, Fragilariaceae, Eunotiaceae. Gustav Fischer Verlag, Stuttgart

Krammer K, Lange-Bertalot H (1991b) Bacillariophyceae. 4: Achanthes, Kritische Ergänzunhen zu Navicula (Lineolatae) und Gomphonema Gesamtliteraturverzeichnis Teil 14. Gustav Fischer Verlag, Stuttgart

Krishnaswamy S, Lal D, Martin JK, Meybeck M (1971) Geochronology of lake sediments. Earth Planet Sci Lett 11:407-414. doi:10.1016/0012-821X(71)90202-0

Kurian GT (1989) Geo-Data: the world geographical encyclopaedia. Gale Research Co., Detroit

Mackay N (1988) Water quality of the River Murray: Review of monitoring 1978-1986. Murray-Darling Basin Commission, Canberra

Moser KA, MacDonald O, Smol JP (1996) Applications of freshwater diatoms to geographical research. Prog Phys Geogr 20(1):21-52. doi:10.1177/030913339602000102

Reavie ED, Hall RI, Smol JP (1995) An expanded weightedaveraging model for inferring past total phosphorus concentrations from diatom assemblages in eutrophic British Columbia (Canada) lakes. J Paleolimnol 14:49-62. doi: 10.1007/BF00682593

Reed JM (1998) A diatom-conductivity transfer function for Spanish salt lakes. J Paleolimnol 19:399-416. doi: 10.1023/A:1007934627134

Reid MA (1997) A diatom-based palaoeecological study of Goulburn River billabongs, south eastern Australia. Unpublished PhD Thesis, Monash University, Melbourne, Australia

Reid MA, Ogden R (2009) Factors affecting the distribution of diatoms in billabong surface sediments from the Murray Basin, southeastern Australia. J Paleolimnol 41:453-470. doi:10.1007/s10933-008-9236-0

Reid MA, Fluin J, Ogden RW, Tibby J, Kershaw AP (2002) Long-term perspectives on human impacts on floodplainriver ecosystems, Murray-Darling Basin, Australia. Verhandlung Int Vereinigung Limnol 28(2):710-716

Reid MA, Sayer CD, Kershaw AP, Heijnis H (2007) Palaeolimnological evidence for submerged plant loss in a floodplain lake associated with accelerated catchment soil erosion (Murray River, Australia). J Paleolimnol 38(2):191-208. doi:10.1007/s10933-006-9067-9

Sayer CD (2001) Problems with the application of diatom-total phosphorus transfer functions: examples from a shallow English lake. Freshw Biol 46(6):743-757. doi:10.1046/ j.1365-2427.2001.00714.x

Simpson GL (2007) Analogue methods in palaeoecology: using the analogue package. J Stat Softw 22:1-29

Sonneman JA, Walsh CJ, Breen PF, Sharpe AK (2001) Effects of urbanization on streams of the Melbourne region, Victoria, Australia. II. Benthic diatom communities. Freshw Biol 46(4):553-565

Stevenson AC, Juggins S, Birks HJB, Anderson DS, Anderson NJ, Battarbee RW, Berge F, Davis RB, Flower RJ, Haworth EY, Jones VJ, Kingston JC, Kreiser AM, Line JM, Munro MAR, Renberg I (1991) The surface waters acidification project Paleolimnology programme: modern diatom/lake water chemistry data-set. ENSIS, London

Tibby J (2000) The development of a diatom-based model for inferring total phosphorus and application to Burrinjuck 
Reservoir, southern New South Wales, Australia. Unpublished $\mathrm{PhD}$ thesis, School of Geography and Environmental Science, Monash University

Tibby J (2001) Diatoms as indicators of sedimentary processes in Burrinjuck Reservoir, southern NSW, Australia. Quaternary Int 83-85:245-256. doi:10.1016/S1040-6182(01) 00043-X

Tibby J (2004) Development of a diatom-based model for inferring total phosphorus in south-eastern Australian water storages. J Paleolimnol 31:23-36. doi:10.1023/ B:JOPL.0000013272.25122.2a

Tibby J, Reid M (2004) A model for inferring past conductivity in low salinity waters derived from Murray River diatom plankton. Mar Freshw Res 55:587-607. doi:10.1071/ MF04032

Tibby J, Reid M, Fluin J, Hart BT, Kershaw AP (2003) Assessing long-term $\mathrm{pH}$ change in an Australian river catchment using monitoring and palaeolimnological data. Environ Sci Technol 37(15):3250-3255. doi:10.1021/ es0263644

Tibby J, Gell P, Fluin J, Sluiter I (2007) Diatom-salinity relationships in wetlands: assessing the influence of salinity variability on the development of inference models. Hydrobiologia 591(1):207-218. doi:10.1007/ s10750-007-0803-6 